\title{
KARAKTERISTIK MOCAF (Modified Cassava Flour) BERDASARKAN METODE PENGGILINGAN DAN LAMA FERMENTASI
}

Characterization of The MOCAF (Modified Cassava Flour) Based on Milling Method and Fermentation Time

\author{
Nia Ariani Putri ${ }^{1} *$, Herlina Herlina ${ }^{1)}$, Achmad Subagio $^{1)}$ \\ ${ }^{1)}$ Program Studi Magister Teknologi Agroindustri, Fakultas Teknologi Pertanian, Universitas Jember \\ Jalan Kalimantan No. 37, Kampus Bumi Tegal Boto Jember 68121, Indonesia \\ *E-mail: nia.arianiputri@yahoo.co.id
}

\begin{abstract}
MOCAF or modified cassava flour is one of modified starch products by biochemical process through fermentation. In fermentation process, lactic acid bacteria (LAB) had the important role to change the structure of the starch by producing enzymes that hydrolyzed the starch. Beside fermentation, the milling process would also damage the starch. The aim of this research was to know the influence of different milling method (wet- and dry milling) and fermentation time on MOCAF charcterization. Different milling process (wet and dry milling) and the long of fermentation process influenced the value of $\mathrm{pH}$, water holding capacity, swelling power, sineresis, and morphology properties of MOCAF starch granule, but did not influence the whiteness and pasta clarity of MOCAF. MOCAF which was produced by wet milling process had lower $p H$ (4,24-5,98), water holding capacity (122-162\%) and swelling power (308-397\%), and higher syneresis value than $M O C A F$ which was produced by dry milling proces. Fermentation produced MOCAF with higher whiteness value and more damaged starch granule.
\end{abstract}

Keywords: MOCAF, milling, fermentation, starch granule

\section{PENDAHULUAN}

MOCAF (Modified Cassava Flour) atau tepung ubi kayu termodifikasi merupakan salah satu produk pati termodifikasi yang telah banyak dimanfaatkan pada berbagai produk pangan. Menurut Subagio et al. (2008), MOCAF merupakan tepung ubi kayu yang diproduksi dengan memodifikasi sel ubi kayu secara fermentasi.

Modifikasi diartikan sebagai perubahan struktur molekul yang dapat dilakukan dengan beberapa metode, baik secara fisik, kimia, maupun enzimatis (Koswara, 2013). Proses modifikasi pada produksi MOCAF merupakan proses modifikasi secara biokimia, yaitu dengan menambahkan enzim atau mikroba penghasil enzim (Herawati, 2010). Bakteri asam laktat (BAL) berperan penting dalam proses fermentasi, dimana aktivitasnya dapat menghasilkan enzim pektinolitik dan sellulolitik yang dapat menghancurkan dinding sel ubi kayu, serta menghidrolisis pati menjadi asam-asam organik (Subagio, et al., 2008).

Modifikasi pati dilakukan dikarenakan dalam penggunaannya, pati alami memiliki beberapa kelemahan yang ditunjukkan dengan munculnya karakteritik yang tidak diinginkan pada kondisi $\mathrm{pH}$, suhu, dan tekanan tertentu. Modifikasi pati dapat memperbaiki karakteristik yang dihasilkan. Menurut Aini et al. (2016), karakteristik tepung sangat menentukan penggunaannya pada produk pangan yang erat hubungannya dengan kualitas produk tersebut.

Menurut Subagio et al. (2008), proses fermentasi pada MOCAF mengakibatkan perubahan karakteristik pada tepung seperti meningkatnya nilai viskositas, kemampuan gelasi, daya rehidrasi, dan kemudahan melarut. Hal 
serupa juga diungkapkan oleh Aini et al. (2016) bahwa modifikasi tepung secara enzimatik menunjukkan perubahan sifat fisikokimia dan fungsional tepung.

Tidak hanya itu, proses penggilingan (basah dan kering) serta proses fermentasi akan mempengaruhi karakteristik morfologi granula pati. Proses penggilingan dapat mengakibatkan pati mengalami kerusakan. Menurut Leon et al. (2006), selama proses penggilingan beberapa granula pati mengalami kerusakan secara mekanis, dimana tingkat kerusakannya bervariasi bergantung pada kekerasan biji dan kondisi proses penggilingan.

Hal tersebut juga akan mempengaruhi karakteristik tepung yang dihasilkan. Oleh karena itu, perlu dilakukan penelitian untuk mengetahui pengaruh metode penggilingan (basah dan kering) dan lama fermentasi pada produksi MOCAF terhadap karakteristik MOCAF yang dihasilkan.

\section{METODE PENELITIAN}

\section{Alat dan Bahan}

Alat untuk produksi dan ekstraksi pati MOCAF meliputi pisau, mesin slicer, bak fermentasi, neraca analitik, tampir, blender (basah dan kering) merk Maspion, sentrifuse, oven, dan ayakan 100 mesh dan 200 mesh. Untuk analisis alat yang dibutuhkan meliputi alat-alat gelas, waterbath, $\mathrm{pH}$ meter, turbidimeter, colour reader dan cawan petri, serta mikroskop trinokuler merk Olympus BX43. Bahan yang digunakan yaitu ubi kayu varietas ketan yang berusia 10 bulan, diperoleh dari kecamatan Gumukmas, Kabupaten Jember, starter MOCAF, aquades, dan air.

\section{Tahapan Penelitian \\ Produksi MOCAF}

Proses produksi MOCAF meliputi beberapa tahapan proses antara lain proses pengupasan, pencucian, pengecilan ukuran, fermentasi, pengeringan dan penepungan, serta pengayakan (Subagio, et al., 2008). Pada penelitian ini, proses produksi MOCAF dilakukan dengan menggunakan metode penggilingan (basah dan kering) dan lama fermentasi yang berbeda. Sebelum memulai proses produksi, bahan yang akan digunakan harus telah disesuaikan dengan kriteria yaitu ubi kayu yang berusia 10 bulan. Setelah itu, menyiapkan alat dan bahan lain yang dibutuhkan pada proses produksi.

Langkah awal yang dilakukan yaitu pengupasan ubi kayu menggunakan pisau pengupas dengan tujuan untuk memisahkan kulit ubi kayu. Selanjutnya, ubi kayu yang telah dikupas dicuci dengan menggunakan air untuk menghilangkan kotoran yang menempel pada permukaan ubi kayu. Pada proses ini dihasilkan limbah cair sisa proses pencucian. Setelah ubi kayu bersih, ubi kayu tersebut dipotong tipis-tipis menggunakan mesin slicer sehingga berbentuk chip. Chips ubi kayu tersebut kemudian dilakukan proses fermentasi. Proses fermentasi merupakan tahapan yang penting, yang tidak dilakukan pada proses pembuatan tepung ubi kayu.

Proses fermentasi dilakukan dengan menambahkan starter MOCAF dan air dengan perbandingan $(1: 1000)$. Pada penelitian ini, waktu fermentasi divariasikan menjadi beberapa waktu yaitu $0,6,12,18$, dan 24 jam. Limbah cair juga dihasilkan pada proses fermentasi ini. Setelah proses fermentasi selesai, tahap selanjutnya yaitu proses pengeringan dan penepungan. Pada tahap inilah yang membedakan tahapan proses produksi dengan metode penggilingan basah dan kering.

Pada metode penggilingan kering, chips ubi kayu yang telah difermentasi dikeringkan dengan menggunakan sinar matahari (sun drying) sehingga dihasilkan chips MOCAF. Chips MOCAF tersebut kemudian digiling dengan menggunakan blender kering selama satu menit. 
Selanjutnya tepung yang dihasilkan dari proses penggilingan tersebut dilakukan pengayakan dengan menggunakan ayakan 100 mesh, sehingga dihasilkan MOCAF dengan metode penggilingan kering.

Berbeda dengan metode penggilingan kering, pada metode penggilingan basah chips ubi kayu yang telah difermentasi tersebut digiling dengan menambahkan air dengan perbandingan (6:1) menggunakan blender basah selama satu menit sehingga dihasilkan dalam bentuk bubur. Setelah itu, bubur tersebut dikeringkan dengan menggunakan sinar matahari hingga kering, sehingga dihasilkan bubur chips MOCAF kering. Bubur chips MOCAF kering tersebut kemudian digiling dengan menggunakan blender kering selama satu menit dan diayak menggunakan ayakan 100 mesh, sehingga dihasilkan MOCAF dengan metode penggilingan basah.

\section{Ekstraksi pati MOCAF}

Proses ekstraksi pati MOCAF meliputi beberapa tahapan proses, yaitu: proses pencampuran, penyaringan, sentrifugasi, pengeringan, dan penghalusan, serta pengayakan. Proses pencampuran dilakukan dengan menambahkan air dengan MOCAF dengan perbandingan (10:1) menggunakan blender selama 10 detik. Selanjutnya suspensi MOCAF tersebut dilakukan penyaringan dengan menggunakan ayakan 200 mesh.

Cairan yang lolos ayakan tersebut kemudian dilakukan sentrifugasi dengan kecepatan 3000 rpm selama lima menit, dan supernatan dipisahkan sehingga hanya tersisa padatannya saja. Setelah itu, padatan tersebut dikeringkan. Proses pengeringan tersebut dilakukan dengan menggunakan oven pada suhu $50^{\circ} \mathrm{C}$ selama 24 jam. Padatan kering yang diperoleh kemudian dihaluskan, dan selanjutnya dilakukan pengayakan dengan menggunakan ayakan 200 mesh sehingga diperoleh pati MOCAF.

\section{RancanganPercobaan}

Penelitian ini menggunakan metode deskriptif dengan dua faktor, faktor pertama yaitu metode penggilingan (basah dan kering); faktor kedua yaitu lama ferementasi $(0,6,12,18$, dan 24 jam). Notasi huruf menunjukkan metode penggilingan, dimana A (metode penggilingan kering), dan B (metode penggilingan basah); sedangkan notasi angka menunjukkan lama fermentasi, yaitu 1 (0 jam), 2 (6 jam), 3 (12 jam), 4 (18 jam), dan 5 (24 jam). Proses produksi MOCAF dilakukan sebanyak tiga kali ulangan pada masing-masing variasi perlakuan.

\section{Metode Analisis}

MOCAF yang diproduksi dengan variasi metode penggilingan dan lama fermentasi akan diuji karakteristik MOCAF dan morfologi granula patinya. Parameter karaktersitik MOCAF yang akan diuji meliputi derajat putih, $\mathrm{pH}$, water holding capacity (WHC), swelling power, sineresis, dan kejernihan pasta.

\section{Pengukuran derajat putih (Mawarni dan Widjanarko, 2015)}

Penentuan nilai derajat putih diukur dengan menggunakan colour reader. Sebelum digunakan, colour reader dikalibrasi terlebih dahulu dengan standar yaitu kertas putih. Setelah itu, sampel diletakkan pada cawan kemudian menentukan lima titik yang akan diukur untuk mengetahui nilai $\mathrm{dL}$, da, dan $\mathrm{db}$. Nilai L, a, dan b sampel diperoleh dengan menjumlahkan nilai $\mathrm{dL}$, da, dan db sampel dan standar. Nilai derajat putih (whiteness) diketahui dengan menggunakan rumus sebagai berikut:

$$
\mathrm{W}=100-\left\{(100-\mathrm{L})^{2}+\mathrm{a}^{2}+\mathrm{b}^{2}\right\}^{0,5}
$$

Pengukuran pH (Dufour, et al., 2002)

Langkah awal yang dilakukan untuk mengukur $\mathrm{pH}$ sampel yaitu dengan membuat suspensi sampel dengan konsentrasi $10 \%$. Selanjutnya, sampel 
tersebut didiamkan agar mengendap pada suhu ruang selama 30 menit. Seteleh itu, suspensi disentrifus dengan kecepatan 3000 rpm selama 10 menit pada suhu $27^{\circ} \mathrm{C}$. Supernatan yang diperoleh dipisahkan dan diukur nilai $\mathrm{pH}$-nya dengan menggunakan $\mathrm{pH}$ meter.

\section{Water holding capacity (WHC) (Subagio,} 2006)

Sebanyak 1 gram sampel ditambah dengan $5 \mathrm{~mL}$ aquades, kemudian dilakukan pengocokan menggunakan vortex pada suhu ruang selama 1 menit hingga homogen. Selanjutnya suspensi tersebut disentrifus dengan kecepatan 3000 rpm selama 10 menit dan dilakukan pemisahan supernatan. Supernatan tersebut kemudian ditimbang. Perhitungan nilai water holding capacity menggunakan rumus sebagai berikut:

$$
\% \mathrm{WHC}=\frac{\text { air } \text { yang terserap }(g)}{\text { berat sampel kering }(g)} \times 100 \%
$$

\section{Swelling power (Kaur et al., 2011)}

Sampel sebanyak 0,1 gram ditambah dengan aquades sebanyak $10 \mathrm{~mL}$ dan dicampur hingga homogen. Suspensi tersebut kemudian dipanaskan pada suhu $60^{\circ} \mathrm{C}$ selama 30 menit. Selanjutnya suspensi didinginkan sesaat sebelum kemudian disentrifuse dengan kecepatan 2500 rpm selama 15 menit. Supernatan dipisahkan kemudian pasta ditimbang. Perhitungan nilai swelling power menggunakan rumus sebagai berikut:

$$
\text { Swelling power }=\frac{\text { berat pasta }(g)}{\text { berat sampel kering }(g)}
$$

\section{Sineresis (Chen, 2003)}

Metode yang digunakan yaitu dengan cara freeze-thaw. Diawali dengan membuat suspensi sampel dengan konsentrasi 5\%, kemudian dipanaskan pada suhu $100^{\circ} \mathrm{C}$ selama 20 menit. Setelah itu, sampel didinginkan pada suhu ruang selama 30 menit dan kemudian disimpan pada suhu $4^{\circ} \mathrm{C}$ selama 16 jam. Selanjutnya dibekukan pada suhu $-16^{\circ} \mathrm{C}$ selama 24 jam dan dicairkan pada suhu $25^{\circ} \mathrm{C}$ selama 4 jam. Air yang keluar kemudian ditimbang. Setelah itu, sampel dibekukan kembali dengan kondisi yang sama hingga lima kali. Perhitungan nilai sineresis digunakan rumus sebagai berikut:

$$
\text { Sineresis }=\frac{\text { air yang keluar }(g)}{\text { berat pasta mula }- \text { mula }(g)}
$$

Kejernihan Pasta (Subagio, 2006)

Suspensi sampel dengan konsentrasi $0,5 \%$ dipanaskan pada suhu $90^{\circ} \mathrm{C}$ selama 30 menit. Selanjutnya dilakukan pengukuran turbiditas dengan mengunakan turbidimeter.

Pengamatan sifat morfologi (Santiago et al., 2013)

Sampel sebanyak 0,1 gram disuspensikan dalam $1 \mathrm{~mL}$ aquades kemudian diambil dua tetes dan diteteskan pada gelas preparat. Selanjutnya, struktur granula pati diamati dengan menggunakan mikroskop trinokuler (Olympus BX43) pada perbesaran 400x.

\section{HASIL DAN PEMBAHASAN}

\section{Derajat Putih}

Derajat putih adalah kemampuan suatu bahan untuk memantulkan cahaya yang mengenai permukaan bahan tersebut (Iswari et al., 2016). Semakin putih warna tepung, maka semakin tinggi pula tingkat penerimaan konsumen terhadap tepung tersebut. Derajat putih MOCAF dapat dilihat pada Tabel 1. Nilai derajat putih tertinggi yaitu pada sampel A4 sebesar 84,0 ; sedangkan nilai derajat putih terendah terdapat pada sampel B1 sebesar 80,6 .

Nilai derajat putih MOCAF pada semua variasi perlakuan bekisar antara 
80,6-84,0. Nilai tersebut menunjukkan bahwa sampel MOCAF berwarna putih sebab mendekati nilai 100 yang diasumsikan sebagai nilai paling sempurna. Namun, sampel MOCAF tersebut masih memiliki derajat putih di bawah syarat mutu MOCAF SNI 7622:2011 yaitu minimal 87 .

Tabel 1. Derajat putih MOCAF

\begin{tabular}{ccrr}
\hline Sampel & Derajat Putih & \multicolumn{1}{c}{$\mathrm{a}$} & \multicolumn{1}{c}{$\mathrm{b}$} \\
\hline A1 & $81,6 \pm 0,0$ & $-2,0 \pm 0,1$ & $12,3 \pm 0,05$ \\
A2 & $80,7 \pm 0,0$ & $-1,8 \pm 0,1$ & $12,9 \pm 0,09$ \\
A3 & $83,0 \pm 0,0$ & $-2,0 \pm 0,2$ & $10,8 \pm 0,00$ \\
A4 & $84,0 \pm 0,0$ & $-2,2 \pm 0,1$ & $9,8 \pm 0,05$ \\
A5 & $83,7 \pm 1,3$ & $-2,2 \pm 0,3$ & $10,6 \pm 1,95$ \\
B1 & $80,6 \pm 0,1$ & $-1,6 \pm 0,2$ & $12,8 \pm 0,02$ \\
B2 & $82,1 \pm 0,1$ & $-2,0 \pm 0,2$ & $11,0 \pm 0,05$ \\
B3 & $82,8 \pm 0,0$ & $-2,1 \pm 0,6$ & $10,4 \pm 0,05$ \\
B4 & $83,3 \pm 0,0$ & $-2,2 \pm 0,1$ & $9,9 \pm 0,02$ \\
B5 & $83,7 \pm 0,0$ & $-2,2 \pm 0,3$ & $9,5 \pm 0,00$ \\
\hline
\end{tabular}

Hal tersebut diduga disebabkan oleh proses pengeringan pada proses produksi MOCAF. Hidayat et al (2009) melaporkan bahwa waktu pengeringan yang lebih singkat dapat meminimalisasi terbentuknya warna coklat akibat proses pencoklatan. Proses pengeringan menggunakan sinar matahari sehingga dipengaruhi oleh kondisi cuaca. Selain dipengaruhi oleh cuaca, sampel dapat terkena sinar matahari hanya pada saat pagi hingga menjelang sore. Ketika malam hari, sampel tidak terkena sinar matahari sehingga diduga pada saat itu berpeluang terjadi reaksi pencoklatan.

Nilai derajat putih MOCAF yang dihasilkan dengan dua metode penggilingan yang berbeda yaitu metode penggilingan kering cenderung sedikit lebih tinggi jika dibandingkan dengan MOCAF dengan metode penggiligan basah. Hal tersebut diduga dikarenakan proses pengeringan pada MOCAF metode penggilingan basah sedikit lebih lama dibandingkan dengan MOCAF yang menggunakan metode penggilingan kering, sehingga peluang terjadi reaksi pencoklatan sedikit lebih besar. Namun perbedaan diantara keduanya tidak terlalu signifikan dapat diketahui dari rentang nilai keduanya yang tidak berjauhan.

Di sisi lain, dengan semakin lama waktu fermentasi, maka nilai derajat putih tepung semakin meningkat. Hal tersebut menunjukkan bahwa dengan semakin lama proses fermentasi pada produksi MOCAF akan menghasilkan tepung dengan warna yang lebih putih. Pernyataan tersebut didukung oleh penelitian yang dilakukan oleh Iswari, et al (2016), bahwa dengan semakin lama proses fermentasi MOCAF menghasilkan MOCAF dengan warna yang semakin putih yang disebabkan oleh adanya degradasi senyawa kompleks oleh mikroorganisme sehingga bahan berpigmen yang terkandung dalam bahan juga ikut terurai dan larut dalam air.

Selain itu, proses fermentasi juga mampu menghambat atau menekan laju reaksi pencoklatan (maillard) yang dapat menyebabkan bahan menjadi berwarna kecoklatan dengan cara merombak gula pereduksi menjadi asam-asam organik. Oleh karena itu, dengan adanya proses fermentasi pada produksi MOCAF dapat meningkatkan derajat putih MOCAF. Dengan demikian, proses fermentasi pada produksi MOCAF memiliki peranan penting dan berpengaruh lebih besar dibandingkan metode penggilingan dalam penentuan derajat putih MOCAF.

pH

$\mathrm{pH}$ atau derajat asam suatu bahan dapat diketahui dengan mengukurnya menggunakan $\mathrm{pH}$ meter. Nilai $\mathrm{pH}$ MOCAF pada semua variasi perlakuan dapat dilihat pada Gambar 1. Nilai $\mathrm{pH}$ sampel MOCAF yang diproduksi dengan menggunakan metode penggilingan kering berkisar 4,75-6,41; sedangkan rata-rata nilai $\mathrm{pH}$ MOCAF dengan metode penggilingan basah berkisar 4,24-5,98. 


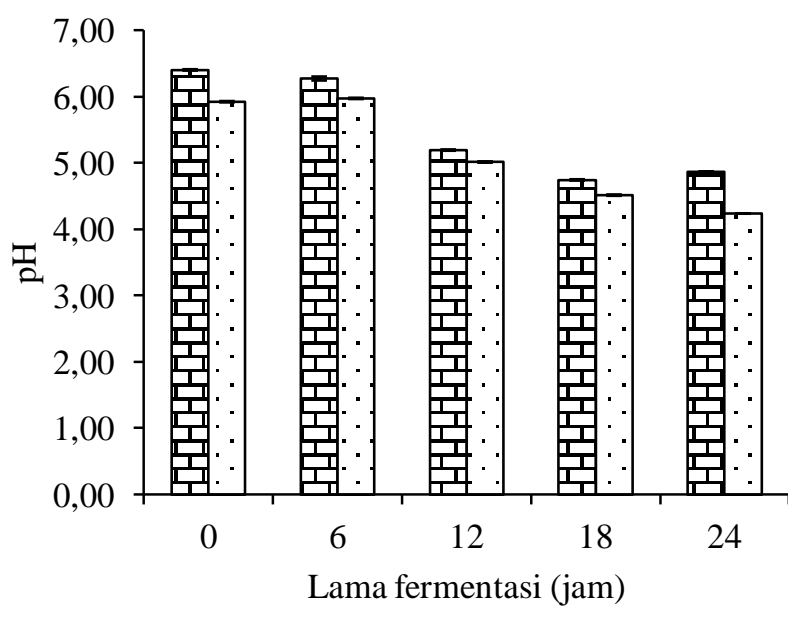

Gambar 1. Nilai $\mathrm{pH}$ MOCAF dengan metode penggilingan kering (四) dan metode penggilingan basah $(\leftarrow \cdot+)$

Gambar 1 menunjukkan bahwa pada sampel MOCAF yang diproduksi dengan menggunakan metode penggilingan basah dan kering pada variasi lama fermentasi memiliki nilai $\mathrm{pH}$ yang berbeda. Nilai $\mathrm{pH}$ MOCAF dengan metode penggilingan basah lebih rendah jika dibandingkan MOCAF yang diproduksi dengan metode penggilingan kering. Hal tersebut menunjukkan bahwa derajat keasaman sampel MOCAF dengan metode penggilingan basah lebih tinggi dibanding MOCAF dengan metode penggilingan kering.

Hasil serupa juga diperoleh oleh Liaotrakoon et al. (2014), dimana nilai $\mathrm{pH}$ tepung job's tear yang diproduksi dengan metode penggilingan basah lebih rendah dibanding tepung yang dihasilkan dengan metode penggilingan kering. Nilai $\mathrm{pH}$ tepung job's tear dengan metode penggilingan basah sebesar 7,03; sedangakn pada tepung job's tear yang menggunakan metode penggilingan kering memiliki nilai $\mathrm{pH}$ sebesar 7,19.

Selain itu, selama proses fermentasi nilai $\mathrm{pH}$ sampel MOCAF baik dengan metode penggilingan basah dan kering mengalami penurunan kecuali pada sampel B5. Penurunan tersebut disebabkan oleh adanya hidrolisis pati menjadi glukosa dan asam-asam organik, terutama asam laktat sehingga semakin lama fermentasi, maka akan semakin banyak pati yang terhidrolisis dan asam laktat yang terbentuk sehingga $\mathrm{pH}$ mengalami penurunan (Subagio et al., 2008). Hal tersebut didukung oleh pernyataan Anggraeni dan Yuwono (2014), dimana nilai $\mathrm{pH}$ tepung ubi jalar terfermentasi semakin menurun seiring dengan lama fermentasi yang dilakukan.

Menurut Subagio et al. (2008), mikroba yang tumbuh pada saat proses fermentasi dapat menghancurkan dinding sel ubi kayu sehingga terjadi liberasi granula pati. Liberasi tersebut akan mengakibatkan perubahan karakteristik pati pada tepung yang dihasilkan. Selanjutnya, granula pati tersebut dihidrolisis oleh mikroba dan menghasilkan monosakarida, dimana monosakarida tersebut pada nantinya akan digunakan sebagai bahan baku untuk menghasilkan asam-asam organik terutama asam laktat.

\section{Water Holding Capacity}

Water holding capacity dapat diartikan sebagai kemampuan pati untuk menyerap air. Nilai WHC sampel MOCAF dapat dilihat pada Tabel 2.

Tabel 2. Water holding capacity MOCAF

\begin{tabular}{cc}
\hline Sampel & $\begin{array}{c}\text { Water holding capacity } \\
(\%)\end{array}$ \\
\hline A1 & $172 \pm 0,08$ \\
A2 & $196 \pm 0,15$ \\
A3 & $180 \pm 0,02$ \\
A4 & $168 \pm 0,05$ \\
A5 & $176 \pm 0,09$ \\
B1 & $122 \pm 0,02$ \\
B2 & $129 \pm 0,02$ \\
B3 & $145 \pm 0,06$ \\
B4 & $149 \pm 0,04$ \\
B5 & $162 \pm 0,02$ \\
\hline
\end{tabular}

Sampel MOCAF dengan metode penggilingan basah memiliki nilai WHC yang lebih rendah dibandingkan sampel MOCAF dengan metode pengilingan 
kering, yaitu berkisar 122-162\% (Tabel 2). MOCAF dengan metode penggilingan kering memiliki nilai WHC antara 172$196 \%$.

Selain itu, selama fermentasi terjadi peningkatan nilai WHC sampel kecuali pada sampel A4 dan A5. Menurut Aini et al. (2016), nilai WHC atau daya ikat air dipengaruhi oleh beberapa faktor, antara lain: perbandingan amilosa dan amilopektin, bobot molekul amilosa dan amilopektin, distribusi bobot molekul, derajat percabangan, panjang dari cabang molekul amilopektin terluar yang dapat berperan dalam kumpulan ikatan.

\section{Swelling Power}

Nilai swelling power pada sampel MOCAF dengan variasi lama fermentasi dan metode penggilingan dapat dilihat pada Tabel 3. Nilai swelling power MOCAF dengan metode penggilingan kering berkisar 357-480\%; sedangkan pada MOCAF dengan metode penggilingan basah memiliki nilai swelling power berkisar 308-397\%, dimana nilai tersebut lebih rendah jika dibandingkan dengan nilai swelling power pada metode penggilingan kering.

Tabel 3. Swelling power MOCAF

\begin{tabular}{cc}
\hline Sampel & Swelling Power $(\%)$ \\
\hline A1 & $368 \pm 0,03$ \\
A2 & $460 \pm 0,48$ \\
A3 & $480 \pm 0,17$ \\
A4 & $370 \pm 0,09$ \\
A5 & $357 \pm 0,19$ \\
B1 & $397 \pm 0,20$ \\
B2 & $363 \pm 0,06$ \\
B3 & $380 \pm 0,30$ \\
B4 & $308 \pm 0,21$ \\
B5 & $318 \pm 0,40$ \\
\hline
\end{tabular}

Swelling power merupakan kemampuan pati untuk mengembang. Nilai swelling power sampel dengan metode penggilingan basah memiliki yang lebih rendah. Selain itu, pada semua sampel nilai swelling power mengalami peningkatan hingga lama fermentasi 12 jam, setelah itu mengalami penurunan hingga lama fermentasi 24 jam.

Menurut Li dan Yeh (2001), terdapat korelasi negatif antara swelling power dengan kadar amilosa, dimana nilai swelling power menurun seiring dengan peningkatan kadar amilosa. Dengan demikian, diduga selama fermentasi terjadi perubahan rantai cabang menjadi rantai lurus yaitu amilosa. Pada metode penggilingan basah diduga memiliki kandungan amilosa lebih tinggi sebab dimungkinkan proses fermentasi masih tetap berlangsung selama proses pengeringan dikarenakan sampel dalam keadaan basah (bubur chips MOCAF). Menurut Babu dan Parimalavalli (2012), kapasitas pembengkakan dipengaruhi oleh ukuran granula, amilosa-lipid komplek dan struktur amilopektin.

\section{Sineresis}

Sineresis dapat diartikan sebagai keluarnya air saat proses pendinginan (pemisahan air dari struktur gelnya). Hasil pengukuran sineresis pada semua sampel dapat dilihat pada Gambar 2.

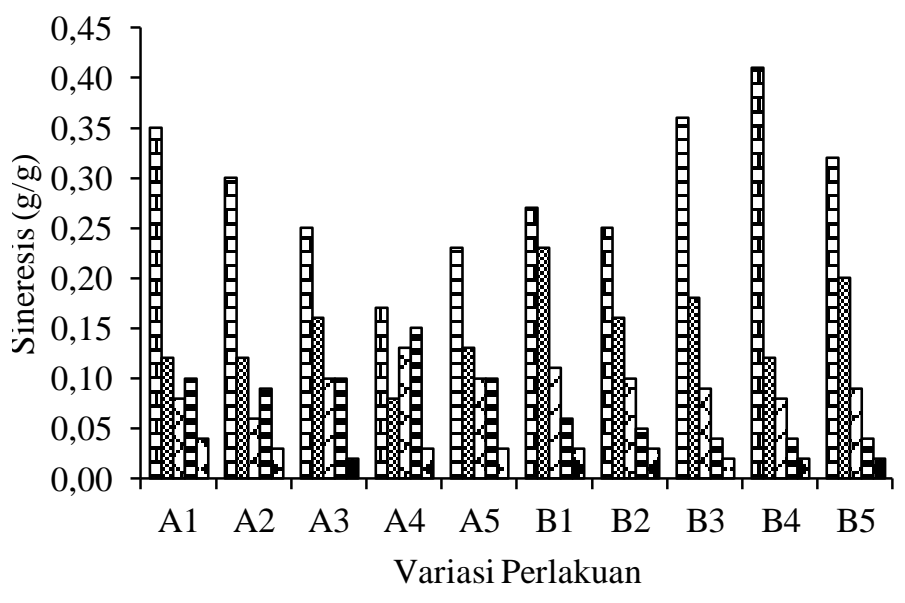

Gambar 2. Nilai sineresis MOCAF pada tiap jam pengukuran: 24 jam (四), 48 jam (雁),

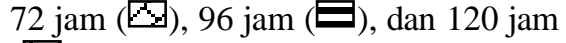
(1)

Sineresis adalah keluarnya air yang terjadi setelah pati telah mengalami 
gelatinisasi dan pendinginan. Untuk mengetahui sineresis yang terjadi pada sampel MOCAF dilakukan pengukuran selama lima hari. Setiap 24 jam, air yang keluar pada setiap sampel diamati dan ditimbang beratnya. Jika diamati, jumlah air yang keluar semakin menurun seiring dengan lama penyimpanan.

Nilai sineresis semakin menurun seiring dengan semakin lama proses penyimpanan. Hal tersebut menunjukkan bahwa semakin lama proses penyimpanan, jumlah air yang keluar pada pasta pati semakin sedikit. Selain itu, dapat dilihat juga bahwa pada sampel dengan metode penggilingan kering memiliki nilai sineresis yang lebih rendah jika dibandingan dengan sampel MOCAF dengan metode penggilingan basah. Hal tersebut diduga dikarenakan kandungan amilosa pada MOCAF dengan metode penggilingan basah lebih besar dibanding pada metode penggilingan kering.

Semakin tinggi nilai sineresis menunjukkan semakin besar pula peluang terjadinya retrogradasi pati yang dapat berpengaruh pada umur simpan produk pangan. Yang memiliki peranan penting dalam hal ini yaitu amilosa. Kandungan amilosa yang tinggi menyebabkan peluang terjadinya retrogradasi lebih tinggi, sebab amilosa akan berikatan kembali setelah proses gelatinisasi pada suhu rendah (pendinginan) (Winarno, 2004). Dengan kata lain, apabila amilosa memiliki kemampuan untuk berikatan kembali yang kuat, maka jumlah air yang keluar juga semakin banyak.

Nilai sineresis pati dengan metode penggilingan basah lebih tinggi dibanding metode penggilingan kering, dan semakin lama fermentasi terjadi penurunan nilai sineresis namun pada lama fermentasi 18 jam meningkat kembali (Gambar 2). Hal tersebut juga diduga disebabkan kandungan amilosa sampel.

\section{Kejernihan Pasta}

Pengukuran kejernihan pasta MOCAF dilakukan dengan menggunakan turbidimeter. Nilai kejernihan pasta MOCAF dengan metode penggilingan basah dan kering dapat dilihat pada Gambar 3.

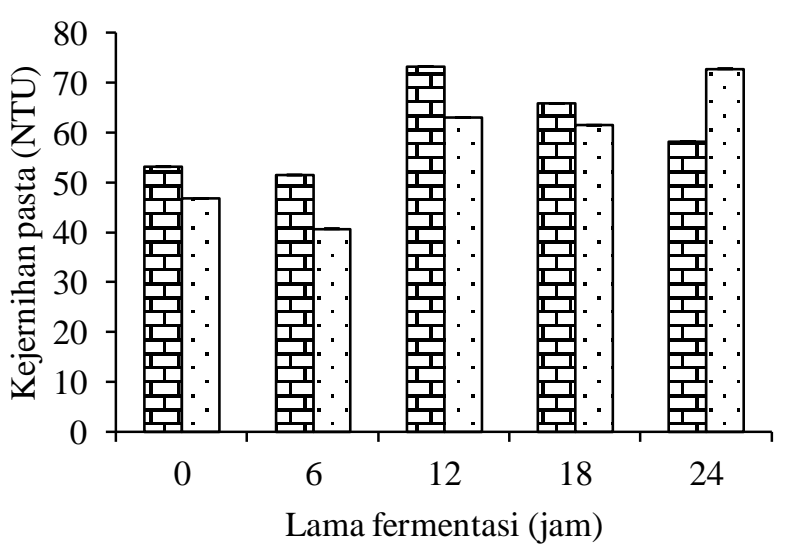

Gambar 3. Nilai kejernihan pasta MOCAF dengan metode penggilingan kering (臣) dan metode penggilingan basah $(\square)$

Nilai kejernihan pasta MOCAF dengan metode penggilingan kering sebesar 51,55-73,35 NTU, sedangkan nilai kejernihan pasta MOCAF dengan metode penggilingan basah sebesar 40,75-72,85 NTU. Nilai kejernihan pasta MOCAF tertinggi yaitu pada sampel A3 dan B5 yang diduga dikarenakan kedua sampel tersebut memiliki nilai derajat putih yang tinggi pula. Metode penggilingan dan lama fermentasi dinilai tidak memiliki peranan penting dalam penentuan kejernihan pasta MOCAF.

\section{Sifat Morfologi Granula Pati}

Sifat morfologi pati MOCAF yang diamati di bawah miroskop trinokuler ditunjukkan pada Gambar 4. Menurut Sangseethong et al., (2010), granula pati ubi kayu alami berbentuk hemispheric, atau bulat dengan ujung terpotong di salah satu bagian dan permukaannya halus dengan tidak ada tanda pecahan atau retakan atau lubang. 
Granula sampel pati MOCAF dengan metode penggilingan kering terlihat lebih bersih jika dibandingkan pada pati MOCAF dengan metode penggilingan basah. Kotoran tersebut diduga adalah selulosa. Selain itu, dengan adanya proses fermentasi mengakibatkan granula pati mengalami patahan atau retakan.

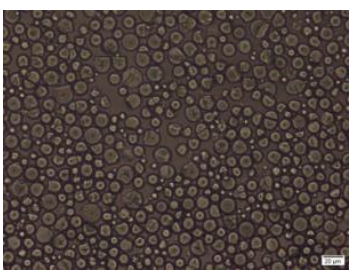

A1

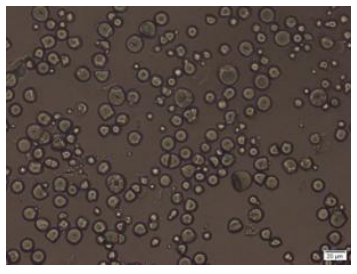

A2

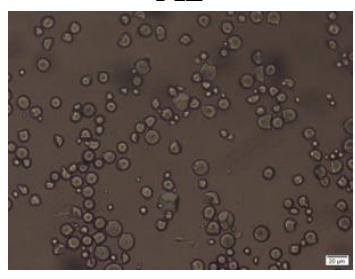

A3

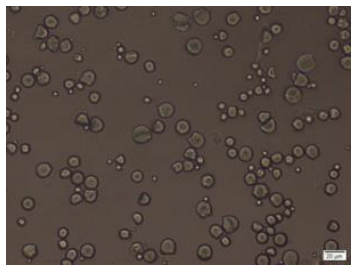

A4

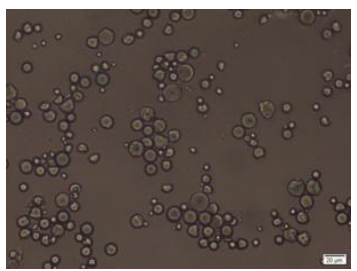

A5

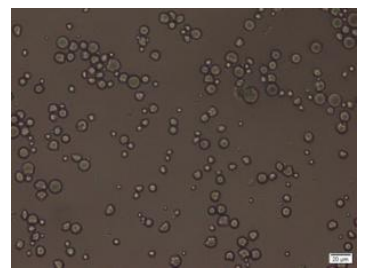

B1

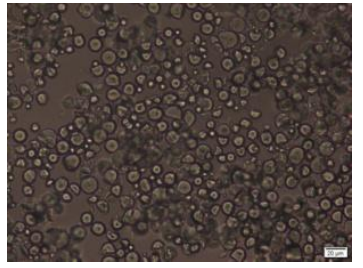

B2

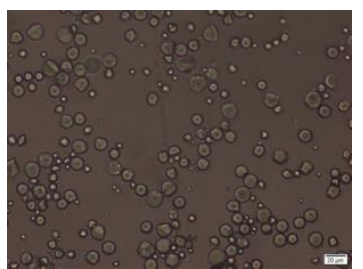

B3

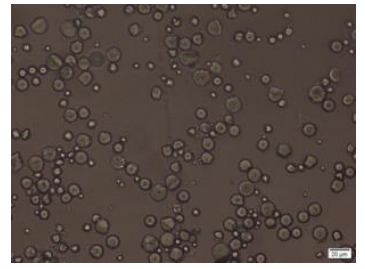

B4

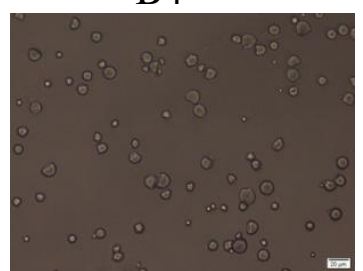

B5
Gambar 4. Morfologi pati MOCAF dengan perbesaran 400x pada metode penggilingan kering (A) dan metode penggilingan basah (B) serta variasi lama fermentasi 0 jam (1), 6 jam (2), 12 jam (3), 18 jam (4) dan 24 jam (5)
Patahan dan retakan yang terjadi selama proses fermentasi diduga disebabkan oleh adanya serangan enzimatis selama proses fermentasi berlangsung. Hal tersebut didukung oleh pernyataan Marcon et al. (2006) yang melaporkan bahwa mereka mengamati lubang kecil pada granula pati ubi kayu asam, yang membuktikan bahwa terdapat adanya serangan secara enzimatis yang mungkin diakibatkan dari enzim yang diproduksi saat proses fermentasi.

Pernyataan tesebut juga selaras dengan pendapat Subagio et al. (2008) sesuai dengan yang telah dijelaskan sebelumnya bahwa aktivitas mikroorganisme pada saat proses fermentasi dapat menghancukan dinding sel ubi kayu sehingga terjadi perubahan karakteritik pada tepung yang dihasilkan.

\section{KESIMPULAN}

Metode penggilingan dan lama fermentasi berpengaruh terhadap penentuan nilai $\mathrm{pH}$, water holding capacity, swelling power, sineresis MOCAF, dan sifat morfologi granula pati MOCAF namun tidak berpengaruh pada penentuan nilai kejernihan pasta MOCAF. Derajat putih MOCAF lebih dipengaruhi oleh lama fermentasi.

Metode penggilingan basah menghasilkan MOCAF dengan $\mathrm{pH}$ lebih asam, nilai water holding capacity dan swelling power lebih rendah, nilai sineresis lebih tinggi jika dibandingkan dengan MOCAF yang dihasilkan dengan metode penggilingan kering. Dengan semakin lama fermentasi mengakibatkan MOCAF menjadi lebih putih dan granula pati lebih mengalami kerusakan.

\section{UCAPAN TERIMA KASIH}

Ucapan terima kasih ditujukan kepada ARISA (Applied Research and Innovation System in Agriculture) yang telah mendukung secara finansial terlaksananya penelitian yang berjudul starch damage MOCAF (Modified 
Cassava Flour) berdasarkan metode penggilingan dan lama fermentasi.

\section{DAFTAR PUSTAKA}

Aini, N., Wijonarko, G., dan Sustriawan, B. 2016. Sifat fisik, kimia, dan fungsional tepung jagung yang diproses melalui fermentasi. Agritech, 36 (2): 160-169.

Anggraeni, Y. P., dan Yuwono, S. S. 2014. Pengaruh fermentasi alami pada chips ubi jalar (Ipomoea batatas) terhadap sifat fisik tepung ubi jalar terfermentasi. Jurnal Pangan dan Agroindustri, 2 (2): 59-69.

Badan Standarisasi Nasional. 2011. SNI 7622: 2011 Tepung Mokaf.

Chen, Z. 2003. "Physicochemical Properties of Sweet Potato Starches and Their Application in Noodle Products". Thesis. Food Chemistry Faculty, Wageningen University.

Dufour, D., O’brien, G.M., dan Best, Rupert. 2002. Improving The Bread-Making Potential of Cassava Sour Starch. Cassava Flour and Starch: Progress in Research and Development. Centro International de Agricultura Tropical International Center for Tropical Agriculture (CIAT): 133-142, Columbia.

Herawati, H. 2010. Potensi pengembangan produk pati tahan cerna sebagai pangan fungsional. Jurnal Litbang Pertanian, 30 (1): 2011.

Hidayat, B., Kalsum, N., dan Surfiana. 2009. Karakterisasi ubi kayu modifikasi yang diproses dengan menggunakan metode pragelatinsasi parsial. Jurnal Teknologi Industri dan Hasil Pertanian, 14 (2): 148-159.

Iswari, K., Astuti, H. F., dan Srimaryati. 2016. Pengaruh Lama Fermentasi Terhadap Mutu Tepung Cassava Termodifikasi. BPTP Sumatera Barat.
Kaur, M., Oberoi, D.P. S., Sogi, D. S., dan Gill, B. S. 2011. Physicochemical, Morphological, Pasting Properties of Acid Treated Starches From Different Botanical Sources. Journal Food Science Technology,48 (4): 460-465.

Koswara. 2013. Teknologi Modifikasi Pati. EbookPangan.com.

Li, J. Y., dan Yeh, A. I. 2001. Relationship between thermal, rheological characteristics, and swelling power of various starches. Journal Food Engineering, 50: 141-148.

Liaotrakoon, W., Liaotrakoon, V., Wongsaengtham, W., dan Rosdiri, S. 2014. Influnece of dry- and wet- milling process on physicochemical properties, syneresis, pasting profile, and microbial count of jobs tear flour. International Food Research Journal 21 (5): 17451749.

Marcon, M. J. A.,Vieira, K., Santos, K. N., Simas, D., Amboni, R. D. M. C., dan Amantem E. R. 2006. The effect of fermentation on cassava starch microstructure. Journal of Food Process Engineering, 29: 362-372.

Mawarni, R.T., dan Widjanarko, S.B. 2015. Penggilingan Metode Ball Mill Dengan Pemurnian Kimia Terhadap Penurunan Oksalat Tepung Porang. Jurnal Pangan dan Agroindustri,3 (2): 571-581.

Otitoju, G. T. O. 2009. Effect of Dry and Wet Millling processing techniques on the nutrient composition and organoleptic attributes of fermented yellow maize (Zea mays). African Journal of Food Science,3 (4): 113-116.

Sangseethong, K., Termvejyassayanon, N., and Siroth, K. 2010. Characterization of physicochemical properties of hypochlorite- and peroxide-oxidized cassava starches. Carbohydrate Polymer, 82: 44-53.

Subagio, A. 2006. Ubi kayu substitusi berbagai tepung-tepungan.Food Review, 1 (3): 18-22. 
Subagio, A., Windrati, W. S., Witono, Y., dan Fahmi, F. 2008. "Produksi Operasi Standar (POS): Produksi Mocal Berbasis Klaster". Fakultas Teknologi Pertanian, Universitas Jember, Jember.

Winarno, F.G. 2004. Kimia Pangan dan Gizi. Gramedia Pustaka Utama, Jakarta. 